\title{
Slope performance monitoring and management of a pit wall experiencing large-scale deformations near Kalgoorlie, Western Australia
}

\author{
JW Watton PSM, Australia \\ MJ Fowler PSM, Australia
}

\begin{abstract}
This case study demonstrates the successful geotechnical slope performance monitoring and management of an excavated pit slope undergoing large-scale ductile deformations at the Teal open pit gold mine near Kalgoorlie, Western Australia. Most of the eastern wall of the open pit deformed as mining progressed to the target depth of $50 \mathrm{~m}$. Total displacements at the conclusion of mining were in the order of tens of metres and cracking was observed up to $90 \mathrm{~m}$ behind the crest of the pit. Rates of wall displacement in excess of $10 \mathrm{~mm}$ per hour were experienced during mining. The slope deformations experienced at the Teal open pit were successfully managed as a result of highly responsive expert geotechnical slope performance monitoring and management. Slope performance management tools applied at the site included design modifications, a carefully developed trigger action response plan (TARP) and equally importantly, proactive mining operations. Pit slope monitoring comprised prism and slope stability radar monitoring. The application of slope stability radar monitoring and effective slope performance management enabled mining operations to safely continue with slope deformations in excess of conventionally accepted open pit slope performance criteria. The pit was successfully completed at the planned metal grades, with a $5 \%$ surplus in ore mined.
\end{abstract}

Keywords: slope performance management, monitoring, deformation, radar, open pit

\section{Introduction}

This case study demonstrates the successful geotechnical management of a pit wall experiencing large-scale ductile deformations at the Teal open pit gold mine near Kalgoorlie, Western Australia.

The Teal Gold Project is a small-scale open pit gold mine located $11 \mathrm{~km}$ northwest of Kalgoorlie, within the Goldfields Region of Western Australia as shown in Figure 1. The open pit was mined for approximately 18 months, up to early 2018. The open pit is approximately $500 \mathrm{~m}$ long $\times 150 \mathrm{~m}$ wide and was mined to a final depth of approximately $50 \mathrm{~m}$.

This paper is focused on the geotechnical slope performance monitoring and management tools applied in response to high deformations experienced in the eastern wall of the pit.

Pells Sullivan Meynink (PSM) was engaged to provide specialist geotechnical advice for the project. This advice included site investigations, pit slope design parameters and operational pit slope management. Pit slope management comprised site inspections, remote radar monitoring, slope design modifications, development of a ground control management plan (GCMP), and later, a trigger action response plan (TARP).

\section{Geology}

The Teal Gold Project is located $700 \mathrm{~m}$ west of the north-northwest trending Abattoir Shear Zone as shown in Figure 1. Locally, the geology consists of transported sediments overlying caprock and a weathered, foliated sequence of felsic tuffs, porphyries and intermediate volcanics. The volcanic sequence is 
completely weathered to residual saprolitic clays to depths of up to $60 \mathrm{~m}$ (i.e. below the final pit floor). The dominant structural fabric of these rocks is a sub-vertically to steeply southwest dipping relict foliation. The water table was intersected towards the base of the pit.

Gold mineralisation is encountered as an upper supergene zone and a lower hypogene orebody at depth. Mineralisation is thought to be structurally controlled along major shears and splay fault structures.

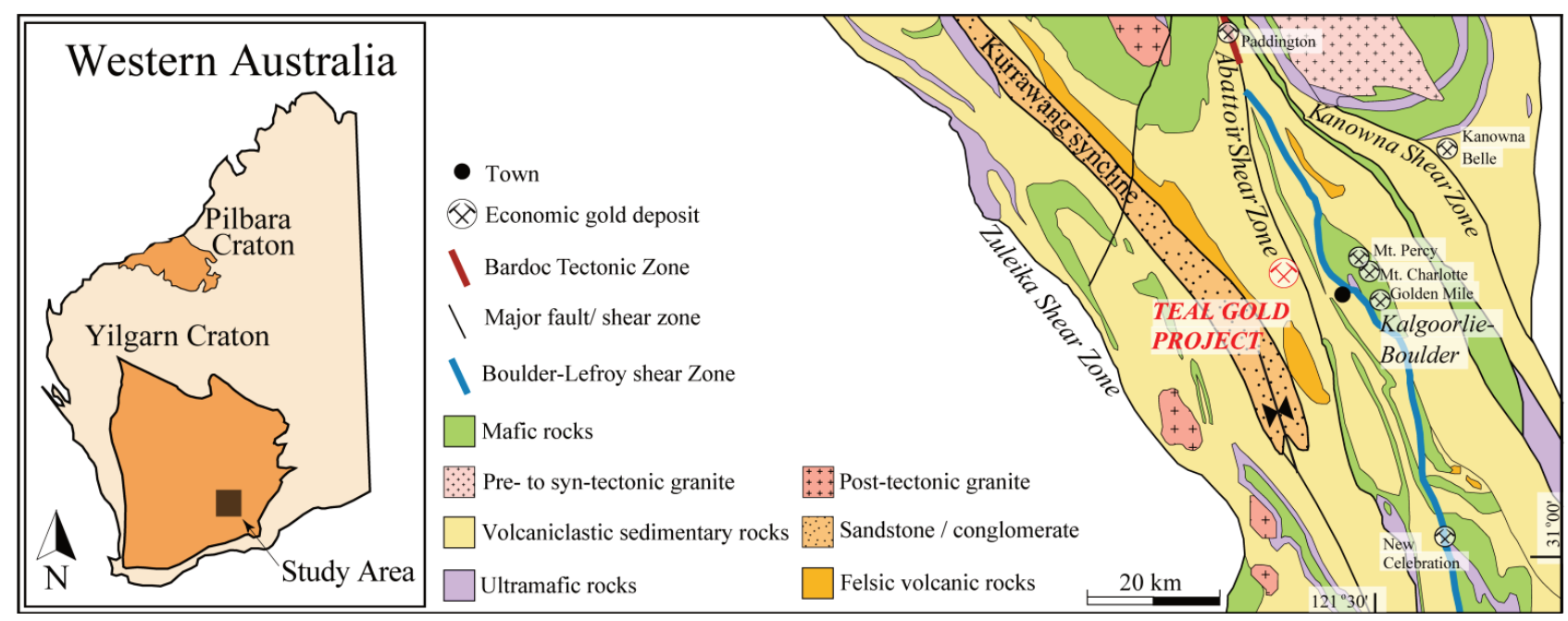

Figure $1 \quad$ Locality and regional geology map (after Morey et al. 2007)

\section{Geotechnical model}

\subsection{Site investigation philosophy}

Geotechnical model development and slope design were based on a limited geotechnical investigation, with a view that uncertainties would be addressed during the early stages of mining with trial slopes and a 'mine and manage' approach to slope stability.

The geotechnical site investigation comprised two geotechnical boreholes with a total length of $145 \mathrm{~m}$. The $\mathrm{HQ} 3$ diameter boreholes were inclined at $60^{\circ}$ and drilled into the east and west walls, near the southern end of the proposed final pit as shown in Figure 2. Figure 2 presents an engineering geological plan of the Teal Gold Project, including:

- Borehole traces.

- Final pit contours.

- Tension cracks.

- Reported instabilities.

Limited field and laboratory testing included:

- Point load and pocket penetrometer testing of core.

- Particle size distribution, Atterberg limits and Emerson Class testing of four disturbed soil samples.

Standpipe piezometers were installed in the two geotechnical boreholes and open resource boreholes were dipped to collect water level data.

Effective strength parameters were estimated from the results of the site investigations and testing listed above. 


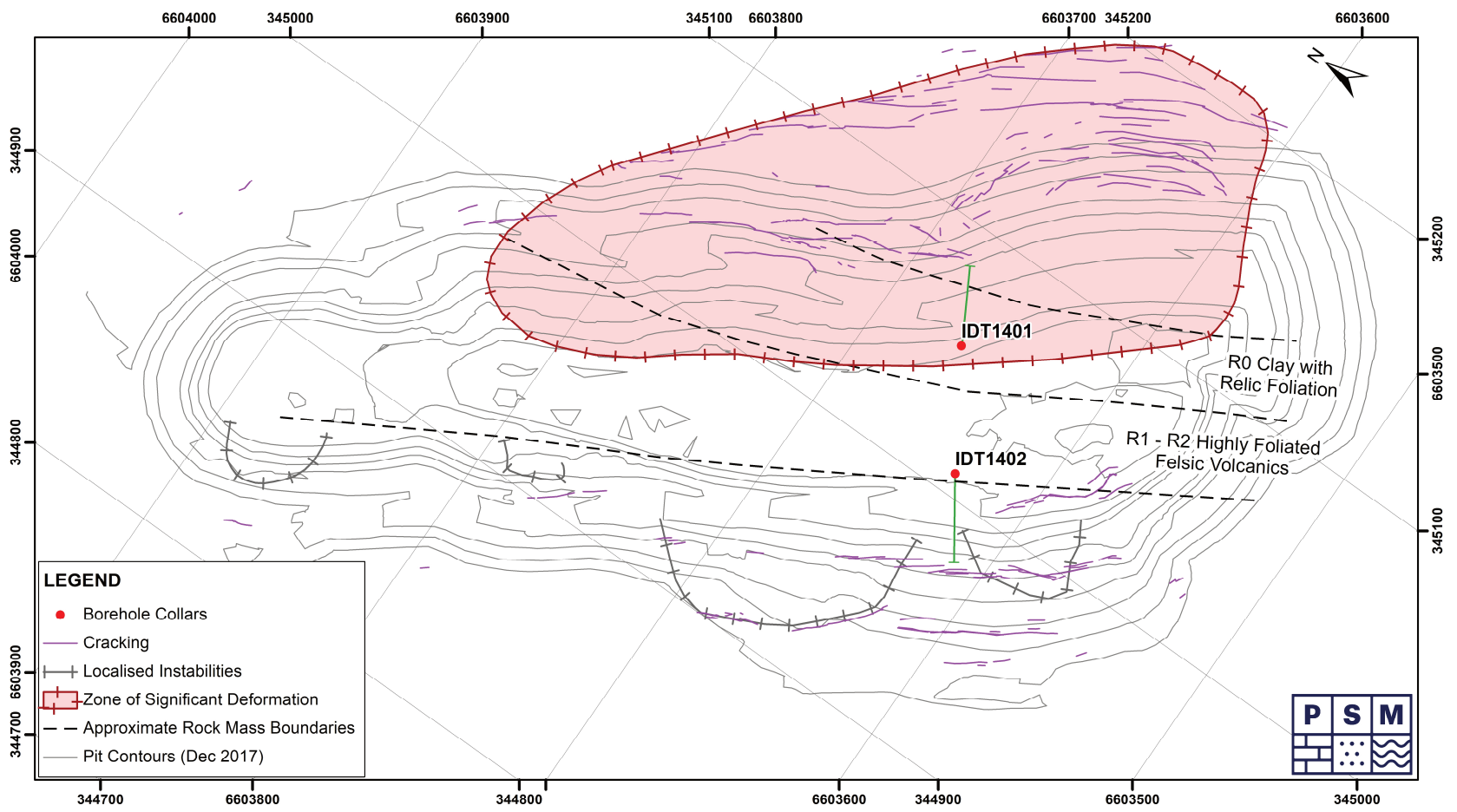

Figure 2 Teal Gold Project site plan, showing instabilities and observed tension cracks

\subsection{Geotechnical model}

The geotechnical model was developed based on a combination of the resources model and the geotechnical drilling. Three geotechnical rock mass domains were defined as described in Table 1 and as shown on the interpretive geotechnical cross-section presented in Figure 3 . The groundwater table was initially estimated to be approximately $40 \mathrm{~m}$ below the ground surface, based on limited observations from nearby boreholes. However, permeability in the clay was interpreted to be relatively low, and any natural drainage from the slope was expected to be limited.

Table $1 \quad$ Summary of geotechnical units

\begin{tabular}{|c|c|c|c|}
\hline $\begin{array}{l}\text { Geotechnical } \\
\text { unit }\end{array}$ & Description & Strength & $\begin{array}{l}\text { Rock quality } \\
\text { designation (\%) }\end{array}$ \\
\hline Caprock & $\begin{array}{l}\text { Typically, the upper } 10 \mathrm{~m} \text { of the deposit. Variably } \\
\text { cemented sandy clay and weathered rock }\end{array}$ & $\mathrm{R} 1-\mathrm{R} 2$ & 80-100 \\
\hline Clay & $\begin{array}{l}\text { Stratigraphically below the caprock. Variable } \\
\text { thickness of up to about } 60 \mathrm{~m} \text { in the east wall. Low } \\
\text { liquid limit silt (from Atterberg limits testing) with } \\
>85 \% \text { fines, however logged as moderately plastic } \\
\text { clay, low dispersivity and slaking potential }\end{array}$ & $\begin{array}{l}\text { R0, zones } \\
\text { of S3 to } \\
\text { S4 }\end{array}$ & 0 \\
\hline $\begin{array}{l}\text { Weathered } \\
\text { felsic volcanics }\end{array}$ & $\begin{array}{l}\text { Stratigraphically below the clay. Metamorphosed, fine } \\
\text { to medium grained felsic volcanics. Extremely to } \\
\text { moderately weathered. Steeply southwest dipping, } \\
\text { wavy foliation with clean or iron stained partings }\end{array}$ & $\mathrm{R} 1-\mathrm{R} 2$ & $60-85$ \\
\hline
\end{tabular}




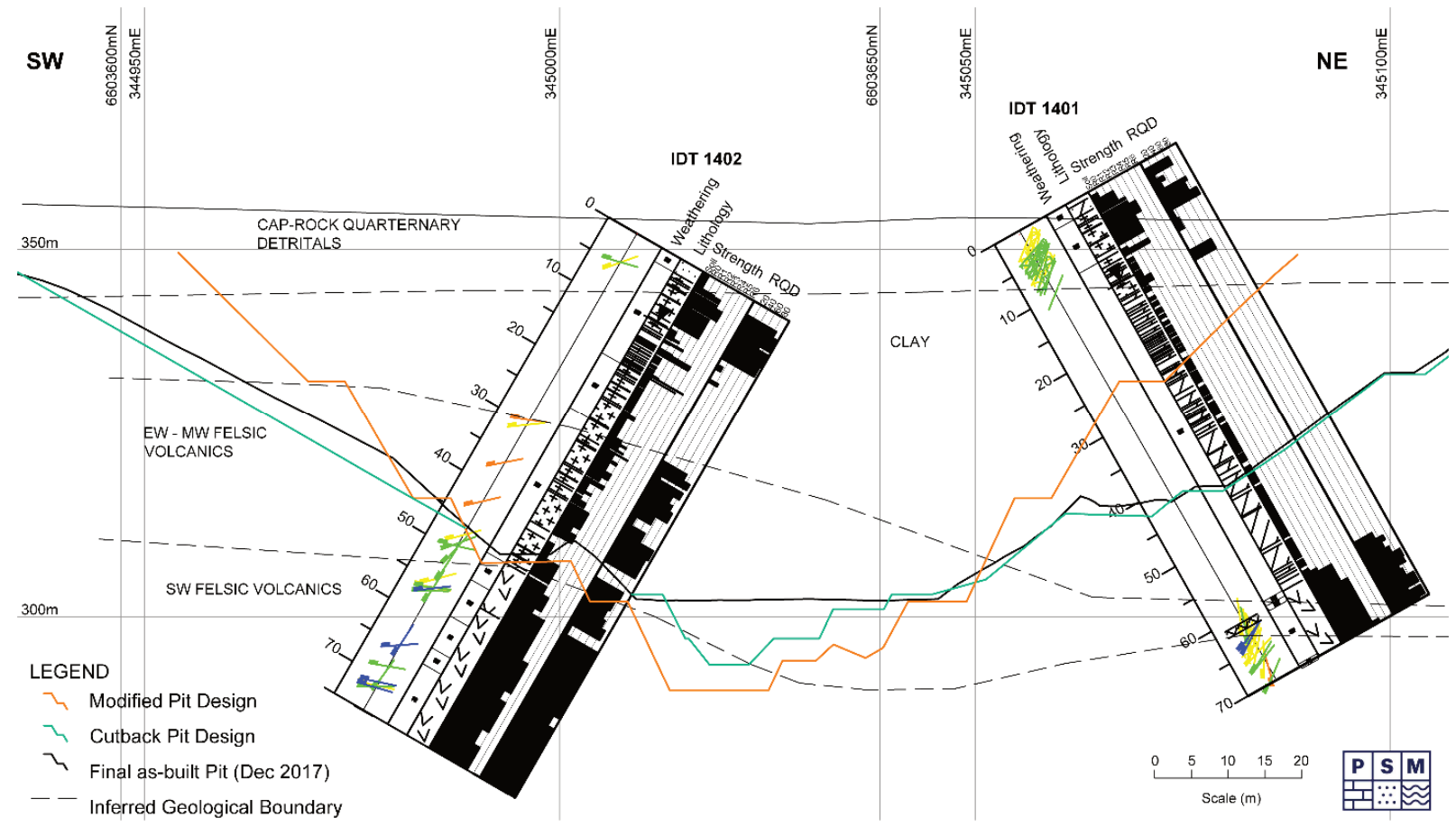

Figure 3 Interpretive cross-section of the Teal Gold Project, showing the deep clay weathering profile

\section{$4 \quad$ Geotechnical analysis and slope design}

A suite of limit equilibrium slope stability analyses was undertaken to estimate the recommended slope design parameters. The recommended overall pit slope angle was assessed to be $40^{\circ}$ on the western pit wall and $32^{\circ}$ on the eastern pit wall. Bench slope configuration is provided in Table 2.

Table 2 Bench slope configuration

\begin{tabular}{lccc}
\hline Geotechnical unit & $\begin{array}{l}\text { Bench face } \\
\text { angle }\left(^{\circ}\right)\end{array}$ & $\begin{array}{l}\text { Berm } \\
\text { width (m) }\end{array}$ & $\begin{array}{l}\text { Bench } \\
\text { height (m) }\end{array}$ \\
\hline Caprock & 65 & 10 & 10 \\
Clay & 45 & 10 & 20 \\
Weathered felsic volcanics & 65 & 8 & 20 \\
\hline
\end{tabular}

Key uncertainties in the slope design included:

- The vertical and lateral distribution of geotechnical units across the deposit. This uncertainty is greatest to the north, away from the geotechnical drilling.

- Structure and material strengths particularly of the clay unit and its depth.

- The extent of slope depressurisation required.

- The risk of instability associated with discrete structures such as faults and shears.

To manage the uncertainties identified, the following geotechnical risk management strategy was recommended:

1. A starter pit with trial slopes.

2. Relocation of the haul road to the eastern wall of the ultimate pit to flatten the higher risk slopes excavated in deeper weak clays.

3. Regular geotechnical pit inspections and pit slope management advice. 


\section{$5 \quad$ Geotechnical risk}

Design modifications in the intervening period between the geotechnical slope design and the commencement of mining resulted in incremental increases in the geotechnical risk profile for the project. These modifications were:

1. Relocation of the haul road from the east wall to the west wall of the pit.

2. A consequent increase in overall slope angle on the eastern pit wall from $32^{\circ}$ to $46^{\circ}$.

3. Commencing excavation of the ultimate pit, thus committing to final slopes with aggressive slope angles.

4. Increasing the pit strike length.

These design modifications combined with the encountered geotechnical conditions resulted in an increased geotechnical risk for the operation. The modified pit design is shown in Figure 3 and a discussion of the increased risk is presented in Section 7.

\section{$6 \quad$ Operational pit slope management}

Pit slope management is an essential component of successful open pit mining, particularly in challenging conditions. A detailed GCMP was developed to manage the operational geotechnical risks at the Teal open pit:

1. Regular walk-over inspections of pit walls to detect signs of ground deformation and instability. This included cracking, slope bulging and toe heave.

2. Documentation of geotechnical observations and the location of any cracking or failures both on plans and in a geotechnical register.

3. Increased frequency of inspections following the identification of instabilities.

4. Geotechnical monitoring comprising prisms and slope stability radar.

5. Geotechnical mapping of pit exposures, with a focus on material strengths and structure in both soils and rock.

6. Measurement of groundwater levels in slopes.

\section{$7 \quad$ Slope deformation and monitoring}

\subsection{Introduction}

Conventional open pit slope design assumes a level of slope performance which is commonly expressed as probability of failure for inter-ramp and bench scale performance of not exceeding say $5 \%$ and $30 \%$ of the slope area respectively (e.g. Wesseloo \& Read 2009).

Significant slope instability was observed during mining. Approximately $75 \%$ of the eastern pit wall and $30 \%$ of the western pit wall deformed during mining as shown in Figure 2. Figures 4 and 5 show examples of slope instability along the western and eastern pit walls, respectively. 


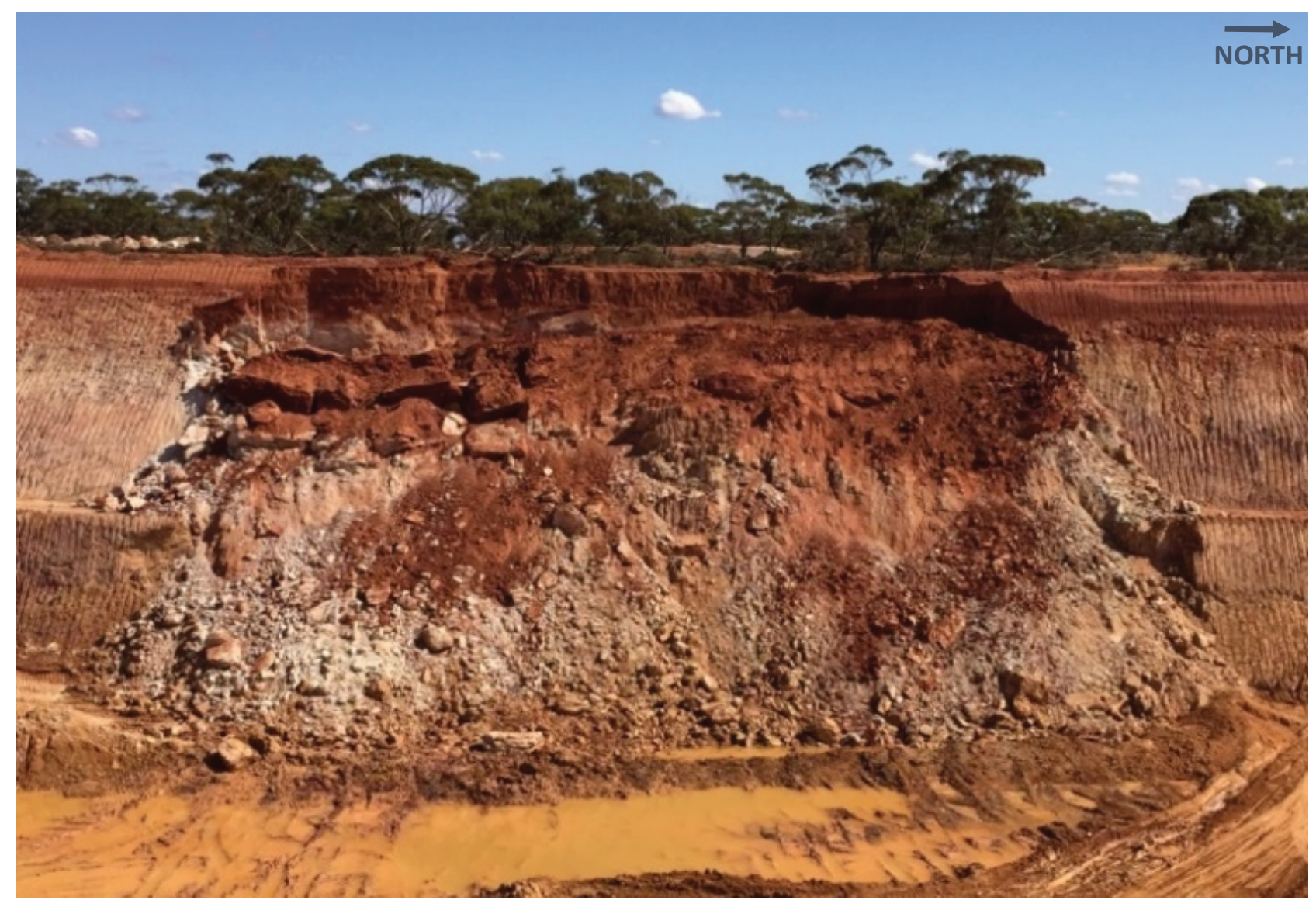

Figure 4 Observed instability along the western pit wall. Instability is $20 \mathrm{~m}$ in height

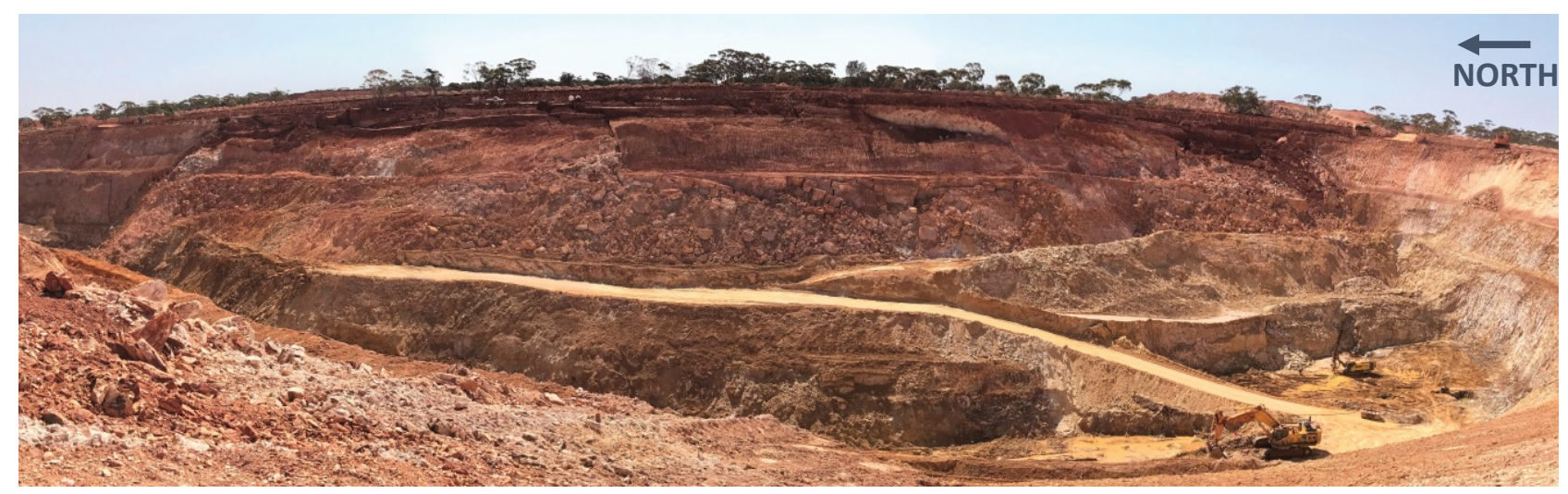

Figure 5 Eastern pit wall before slope unloading, showing the large-scale instability and strategic buttressing material (midground). Pit wall is $40 \mathrm{~m}$ in height

\subsection{Pit slope monitoring and TARP}

Slope monitoring initially consisted of geotechnical inspections and prism monitoring. As the eastern pit wall buttressing material shown in Figure 5 was excavated, slope deformation rates increased significantly, reaching peak deformation rates of greater than $10 \mathrm{~mm} / \mathrm{hr}$. An example of slope displacements from the slope stability radar monitoring as shown in Figure 6.

Increasing deformation rates and exposure ultimately resulted in an increased risk to personnel and equipment in the area. Commensurate with this increased risk, operational geotechnical management was expanded to include more frequent inspections, slope stability radar monitoring and the development of a TARP to control access to the areas at risk of possible failure and run out. 


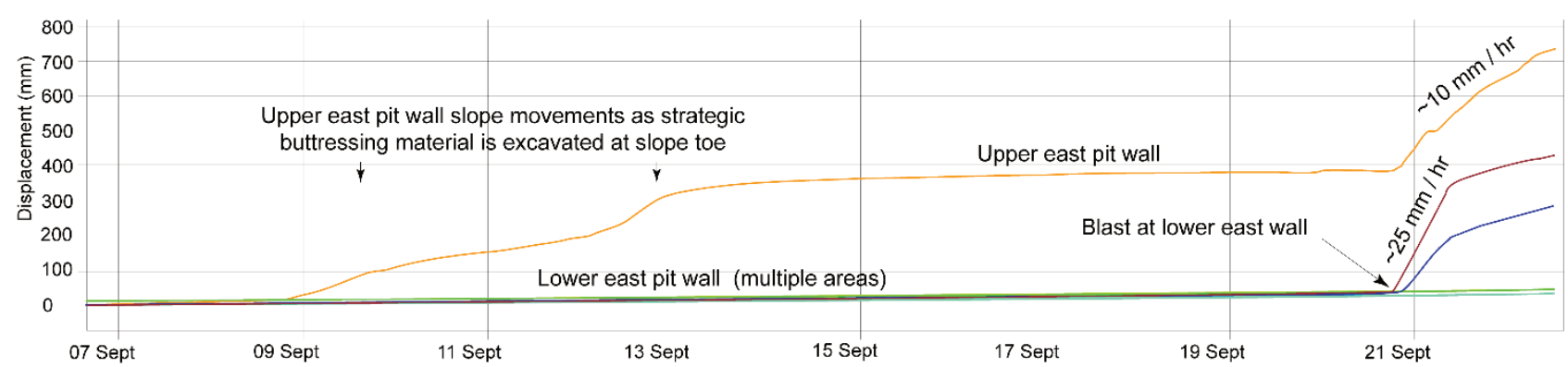

Figure 6 Slope stability radar displacement plot

The TARP utilised both rainfall and displacement triggers. Displacement trigger levels were automated and based on back-analysis of initial radar monitoring, including the time taken for displacement rates to return to prior levels following a blast or failure. The displacement trigger levels are summarised in Table 3. The TARP also established exclusion zones for personnel and equipment most at risk (i.e. people on foot, light vehicles and stationary ancillary equipment such as pumps).

Table 3 Trigger action response plan displacement trigger levels

\begin{tabular}{lccl}
\hline Alert level & $\begin{array}{c}\text { Displacement } \\
\mathrm{mm} / \mathrm{hr}\end{array}$ & $\begin{array}{l}\text { Displacement } \\
\mathrm{mm} / \text { day } \\
\text { (equivalent) }\end{array}$ & $\begin{array}{l}\text { Actions } \\
\text { (abbreviated) }\end{array}$ \\
\hline Green & $<4$ & $<96$ & $\begin{array}{l}\text { Normal operations } \\
\text { Orange }\end{array}$ \\
Red & $4-10$ & $96-240$ & $\begin{array}{l}\text { Increased inspections and } \\
\text { personnel communications }\end{array}$ \\
\hline
\end{tabular}

\section{$8 \quad$ Slope performance management}

\subsection{Slope performance toolbox}

Numerous remedial measures are available for the geotechnical management of unstable pit slopes. The 'slope performance toolbox' (Fowler 2016) is shown in Figure 7 and presents a flow chart of available remediation measures. Typical slope remediation measures comprise:

- Slope stabilisation:

- Controlling groundwater through slope depressurisation and dewatering, and surface water through effective drainage and surface water management.

- Decreasing the instability driving force through slope modifications such as crest unloading or a cutback that flattens the upper slope.

- Increasing the instability resisting force through slope modifications such as toe buttressing, a step-in or flattening of the lower slope.

- Slope reinforcement such as rockbolts or cables, shotcrete and mesh.

- Slope protection such as wall scaling, mesh, ditches, bunds and catch fences.

Selection of the most appropriate combination of remediation options is multi-disciplinary and requires an understanding of the:

- Safety risks to personnel and equipment.

- Geotechnical and hydrogeological model. 
- Failure mechanism and scale.

- Site operational requirements.

- Economic impacts of remediation options.

Once implemented, slope remediation should be monitored for effectiveness and adjusted as appropriate.

\subsection{Failure mechanism and back-analysis}

The major slope failures at the site were interpreted as sliding and dislocation along the steep relict foliation, with toe shearing through weak clays. These failure mechanisms also resulted in tension crack development through the upper caprock unit.

Back-analysis was undertaken to assess the clay unit's strength and included pit observations of the water table, which was located approximately $13 \mathrm{~m}$ below the ground surface at the instability location. The back-analysis results indicated the following:

- Clay unit:

- Material strength: cohesion $=24 \mathrm{kPa}$, friction angle $=31^{\circ}$.

- Foliation strength: cohesion $=0 \mathrm{kPa}$, friction angle $=18^{\circ}$.

The back-analysed clay strengths represent a relatively weak rock mass. The water table at the instability location was significantly closer to the ground surface than indicated by the limited borehole observations. This variation could be due to; the distance between borehole observations to the instability location, compartmentalisation due to structures not intersected by drilling, or changes in the water table over time.

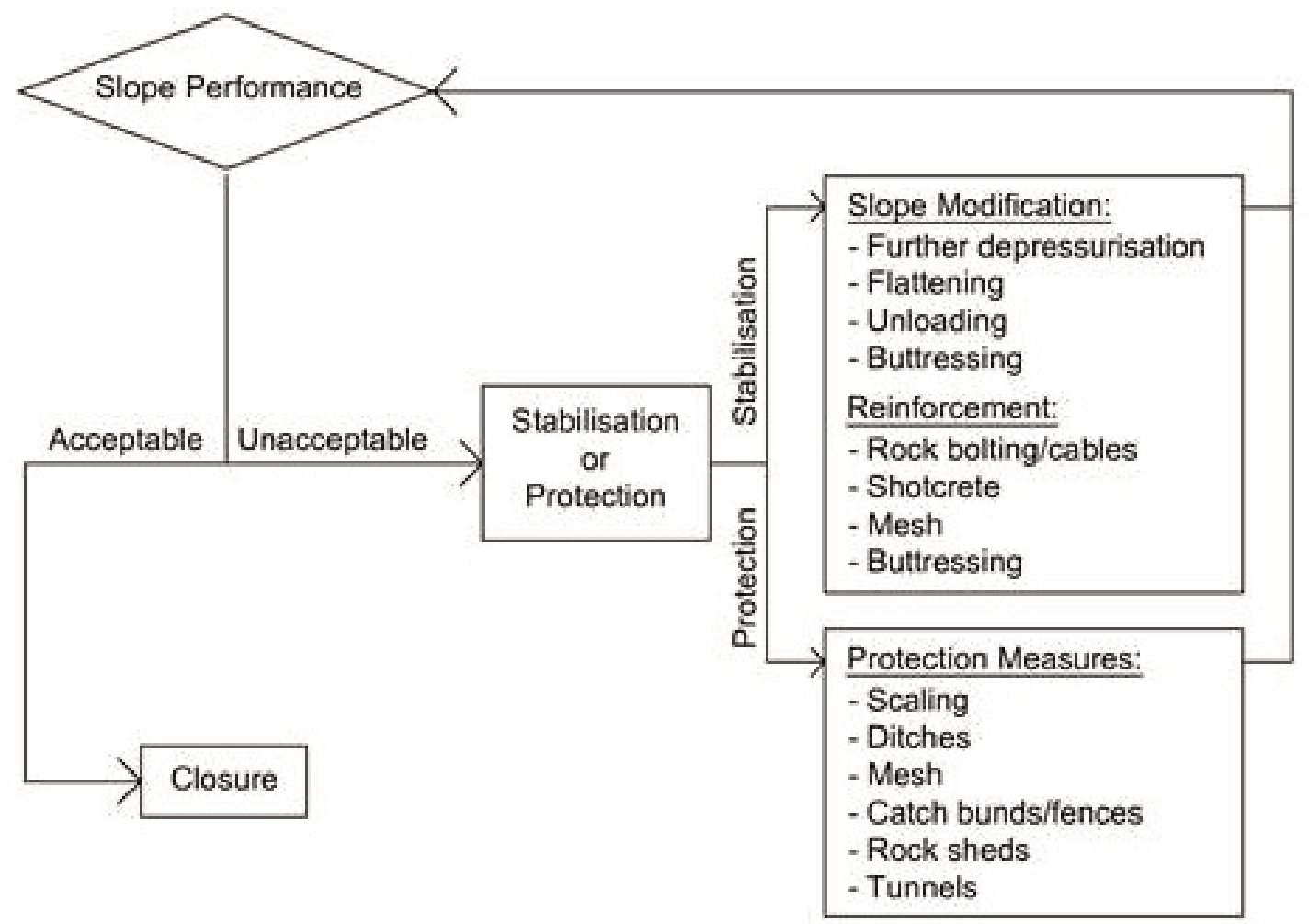

Figure 7 Slope performance toolbox (Fowler 2016)

\subsection{Slope design modification}

The intent of slope design modification at the Teal project was to develop a fit-for-purpose remedial slope design. This fit-for-purpose design would limit future deformations to manageable levels and facilitate the 
safe completion of mining operations. It is important to note that in this case the intent of the remedial design was not to prevent all slope deformation. Two key issues for the management of these failures were:

- Requirement for ongoing mining operations below the instabilities.

- Economic risks to the operation from a permanent step-in in the pit toe position.

Remedial slope modifications primarily comprised strategic toe buttressing of the eastern pit wall to reduce rates of deformation and sterilisation of ore, followed by unloading the pit crest using a cutback as shown in Figures 5 and 8.

To minimise the loss of ore, cutbacks were preferred to a step-in of the design. Limit equilibrium analyses were conducted to assess the unloading requirements and the area was monitored post remediation to evaluate the slope performance and thus confirm the analysis results.

The cutback along the eastern pit wall also included a second ramp access to the pit, reducing the risk of complete loss of access to the open pit and decreasing the overall slope angle for the eastern pit wall.

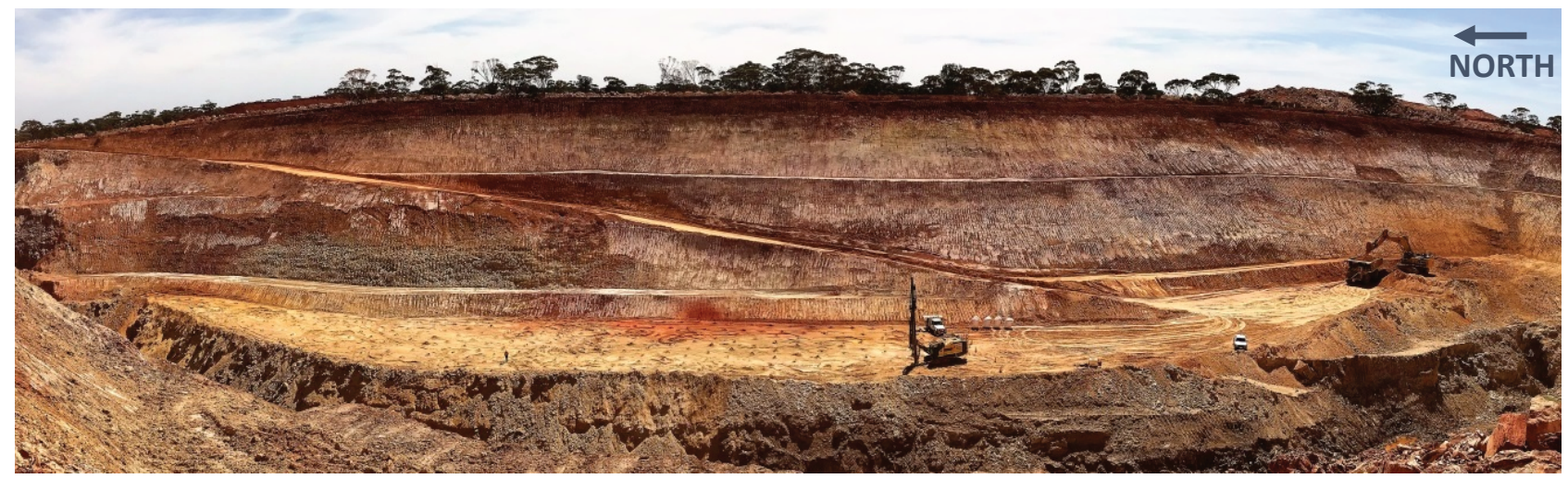

Figure 8 Eastern pit wall after slope unloading and approaching the completion of mining. Pit wall is $40 \mathrm{~m}$ in height

\subsection{Final pit walls}

Deformation of the eastern pit wall continued at manageable rates until the completion of mining, with total displacements of over $10 \mathrm{~m}$ and cracking observed up to $90 \mathrm{~m}$ behind the crest of the eastern pit wall as shown in Figures 9 and 10.

The TARP was continuously implemented from the commencement of mining the material left in place to buttress the eastern pit wall, until the completion of mining the east wall cutback to the planned final depth of $50 \mathrm{~m}$.

The application of precise slope stability monitoring radar at the Teal project allowed for the management of pit slopes deforming in excess of historically manageable rates.

The final excavated slopes achieved overall slope angles of up to $31^{\circ}$ on the eastern pit wall and $39^{\circ}$ on the western pit wall. Table 4 presents the overall slope angle progression throughout the project life. 


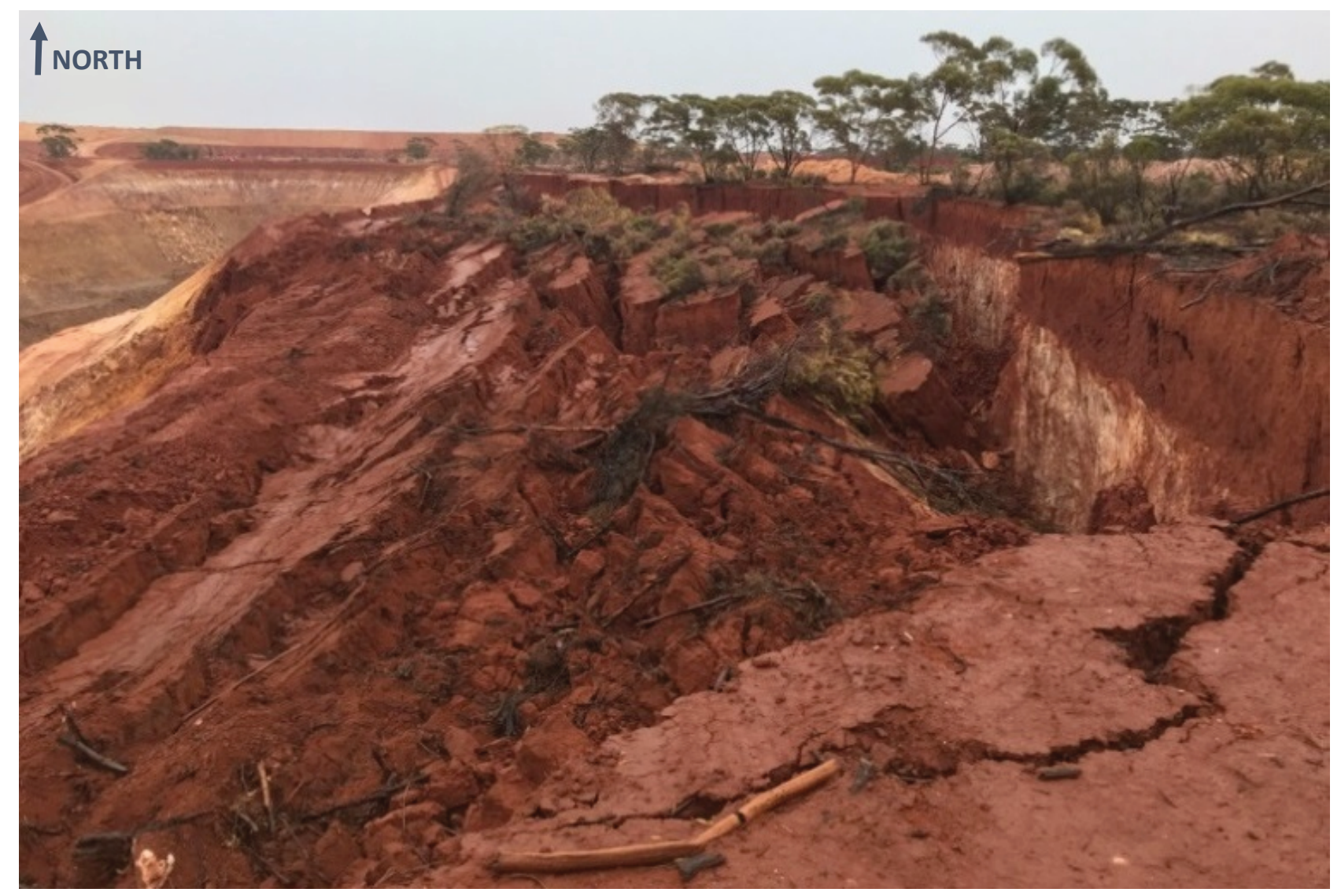

Figure 9 Head-scarp of the eastern pit wall instability at the completion of mining

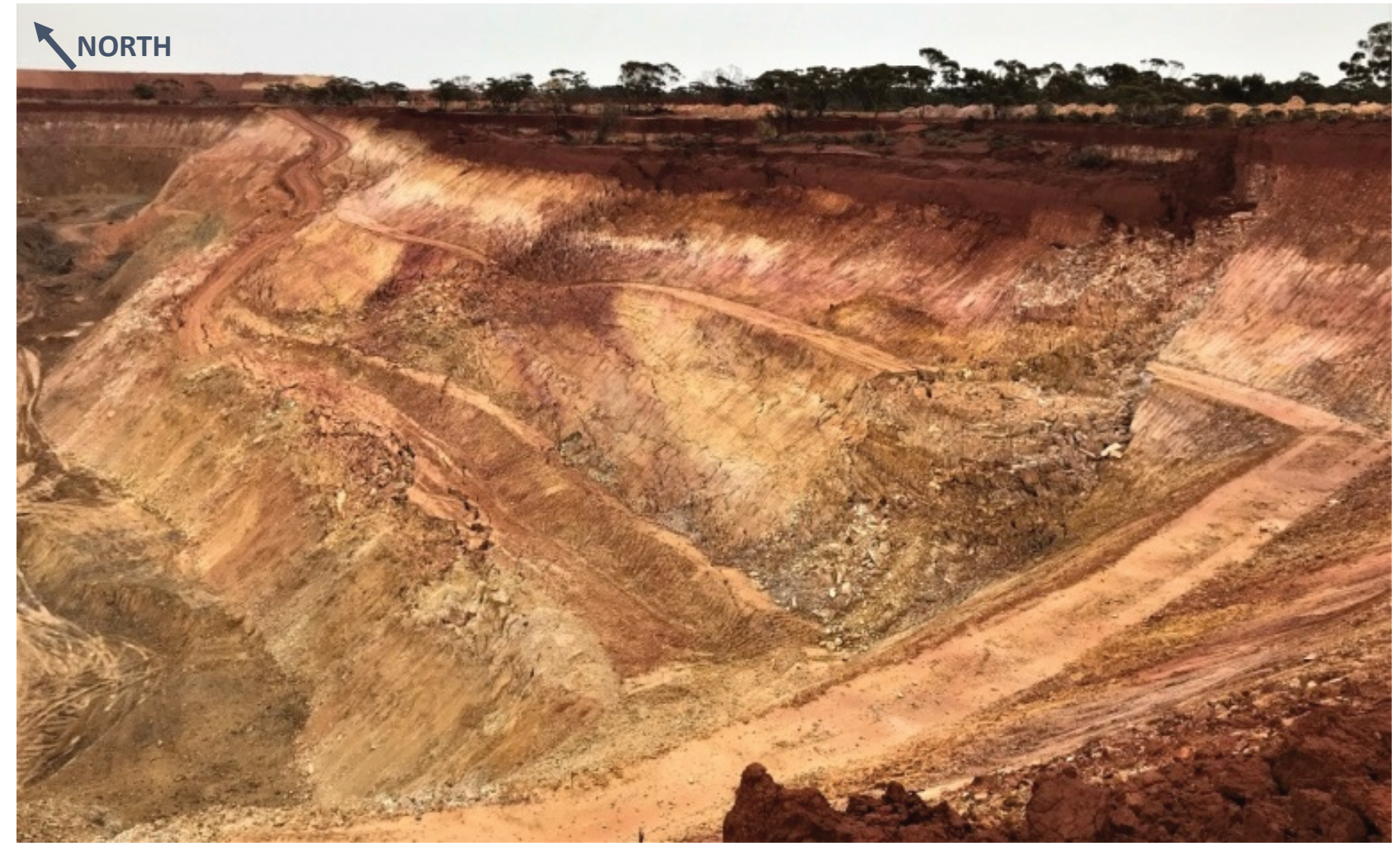

Figure 10 Eastern pit wall instability at the completion of mining. Note the dislocation of benches and deformation of the haul road 
Table 4 Slope angle progression

\begin{tabular}{lll}
\hline Project stage & Eastern wall $\left({ }^{\circ}\right)$ & Western wall $\left(^{\circ}\right)$ \\
\hline PSM slope design & 32 & 40 \\
Modified pre-cutback angle & 46 & - \\
Final overall angle & 31 & 39 \\
\hline
\end{tabular}

\section{Conclusion}

This case study demonstrates the ability to successfully maintain safe mining operations well beyond the conventional open pit slope performance criteria.

This was achieved through focused and expert geotechnical advice regarding remedial slope design and operational management. The remedial slope design advice comprised:

1. Back-analysis to refine the geotechnical model.

2. Changes to excavation sequencing to provide toe buttressing material in order to limit deformations and minimise ore sterilisation.

3. Partial unloading of the deforming slope.

In conjunction, the operational slope management advice included:

1. Geotechnical monitoring comprised of real time slope stability radar, supported by conventional prism monitoring.

2. Development of a detailed GCMP.

3. Regular geotechnical inspections.

4. A carefully formulated and actively revised TARP.

5. Effective communication of operational slope management advice to mining operations personnel.

The Teal open pit was successfully mined to the planned depth of $50 \mathrm{~m}$ and at the planned metal grades, with $5 \%$ additional recovered ore tonnage.

\section{Acknowledgement}

The authors of this paper would like to acknowledge the operational cooperation of key site personnel including Grant Haywood and Nathan Stretton, and thank Intermin Resources for permission to publish this paper. The authors would also like to thank Daniel Strang and Dylan Hemraj of PSM for their valued contributions to the project, and the Australian Geomechanics Society for permission to re-publish parts of this paper presented in Australian Geomechanics, vol. 54, no. 3.

\section{References}

Fowler, MJ 2016, 'The remediation tool box. Management of moving and unstable slopes', PowerPoint presentation presented at the Management of Moving and Unstable Slopes Workshop, 9 September 2016, Brisbane.

Morey, AA, Weinberg, RF \& Bierlein, FP 2007, 'The structural controls of gold mineralisation within the Bardoc Tectonic Zone, Eastern Goldfields Province, Western Australia: implications for gold endowment in shear systems', Mineralium Deposita, vol. 42, no. 6, pp. 583-600.

Wesselloo, J \& Read, J 2009, 'Acceptance criteria', in J Read \& P Stacey (eds), Guidelines for Open Pit Slope Design, CSIRO Publishing, Clayton, pp. 219-234. 
